\title{
THE EFFECT OF CONSUMPTION AND THE LABOUR FORCE PARTICIPATION RATE (LFPR) ON ECONOMIC GROWTH IN NORTH SUMATERA PROVINCE
}

\author{
Indra Maipita \\ Faculty of Economics Universitas Negeri Medan \\ Email: imaipita@gmail.com
}

\begin{abstract}
North Sumatera Provincial Government in implementing regional autonomy and fiscal decentralization policies has tried to implement it based on the needs of each district/city so that a prosperous society is created. The prosperity achieved is not only reflected in high economic growth but is also supported by the fulfillment of realizable consumption needs and the abundant availability of reliable human resources. This study discusses the effect of two variables contained in fiscal decentralization, the level of public consumption and labor absorption on economic growth in North Sumatra. The method used by researchers is regression using panel data (pooled data) or called the panel data regression model. The estimation results show the regression coefficient of the CONS variable is -0.185883 . This means that with each increase in CONS by 1 percent, economic growth will decrease by 0.18 percent and vice versa. The effect of the CONS variable on EG is negative and significant at the 95 percent confidence level and the estimation results show the regression coefficient of the Labour Force Participation Rate (LFPR) variable of 0.442641 . This means that for each increase in LFPR by 1 percent, economic growth will increase by 0.44 percent and vice versa. The effect of the LFPR variable on PE is significant at the 95 percent confidence level.
\end{abstract}

Key words: Consumption; labour force participation rate; economic growth

\section{INTRODUCTION}

$1 \mathrm{n}$ the current era of regional autonomy, good governance is something that cannot be negotiated and absolutely must be fulfilled. Where the two most important variables of good governance are transparency and accountability at the level of budget administrative policies. The spirit of decentralization, democratization, transparency, and accountability has become very dominant in coloring the process of government administration in general and the process of regional financial management in particular.

Regional governments in managing their revenues are always required to be more capable of being independent so that the restructuring process of regional development can be carried out continuously by the priority scale and needs of each region with 
national development targets determined through short and long-term development plans.

In the implementation of national development, the role of local governments in utilizing the available resources in their respective regions is needed to optimize the capacity of their regions. For this reason, the increase must be supported by an integrated and planned development pattern so that appropriate and sustainable development will be realized.

Regional economic development is a process of combining local governments and their communities in managing existing resources and forming a partnership pattern between local governments and the private sector to create new jobs and stimulate the development of economic activity in the region (Arsyad, 1997). Economic development is essentially a business undertaken by the government with the goals of the community of a region has a level of welfare of life and a better economy (Richna et al, 2018).

The rate of economic growth in the regencies/cities of North Sumatera Province from 2013 to 2017 is presented in Table 1 below.

Table 1. The rate of economic growth in the regencies/cities of North Sumatera

Province from 2013 to 2017

\begin{tabular}{|l|l|l|l|l|l|l|}
\hline No & \multicolumn{1}{|c|}{ Regencies / Cities } & $\mathbf{2 0 1 3}$ & $\mathbf{2 0 1 4}$ & $\mathbf{2 0 1 5}$ & $\mathbf{2 0 1 6}$ & $\mathbf{2 0 1 7}$ \\
\hline & Regencies & & & & & \\
2 & Nias & 6,35 & 5,77 & 5,52 & 5,03 & 5,01 \\
3 & Mandailing Natal & 6,37 & 6,49 & 6,21 & 6,18 & 6,09 \\
4 & Tapanuli Selatan & 17,43 & 4,44 & 4,86 & 5,12 & 5,21 \\
5 & Tapanuli Tengah & 5,18 & 5,04 & 5,08 & 5,12 & 5,24 \\
6 & Tobanuli Utara & 5,27 & 5,04 & 4,89 & 4,12 & 4,15 \\
7 & Labuhan Batu & 4,85 & 4,23 & 4,50 & 4,78 & 4,96 \\
8 & Asahan & 5,98 & 5,22 & 5,04 & 5,06 & 5,00 \\
9 & Simalungun & 5,71 & 5,88 & 5,57 & 5,62 & 5,48 \\
10 & Dairi & 5,25 & 5,33 & 5,24 & 5,40 & 5,13 \\
11 & Karo & 5,05 & 5,03 & 5,04 & 5,07 & 4,93 \\
12 & Deli Serdang & 4,95 & 5,09 & 5,01 & 5,17 & 5,21 \\
13 & Langkat & 9,22 & 7,50 & 5,24 & 5,32 & 5,10 \\
14 & Nias Selatan & 5,61 & 5,12 & 5,03 & 4,98 & 5,05 \\
15 & Humbang Hasundutan & 4,65 & 4,32 & 4,43 & 4,48 & 4,60 \\
16 & Pakpak Bharat & 5,72 & 5,54 & 4,63 & 5,02 & 5,07 \\
17 & Samosir & 5,91 & 5,94 & 5,95 & 5,97 & 5,94 \\
18 & Serdang Bedagai & 6,10 & 5,95 & 5,77 & 5,27 & 5,35 \\
19 & Batubara & 5,80 & 5,12 & 5,05 & 5,14 & 5,16 \\
20 & Padang Lawas Utara & 4,23 & 4,20 & 4,14 & 4,47 & 4,11 \\
21 & Padang Lawas & 6,15 & 6,08 & 5,94 & 5,96 & 5,54 \\
22 & Labuhan Batu Selatan & 6,14 & 5,97 & 5,74 & 6,06 & 5,71 \\
23 & Labuhan Batu Utara & 6,05 & 5,31 & 5,14 & 5,19 & 5,09 \\
& & 6,27 & 5,39 & 5,18 & 5,21 & 5,11 \\
\hline
\end{tabular}




\begin{tabular}{|c|c|c|c|c|c|c|}
\hline 24 & Nias Utara & 6,34 & 5,89 & 5,44 & 4,59 & 4,43 \\
\hline 25 & $\begin{array}{l}\text { Nias Barat } \\
\text { City }\end{array}$ & 5,17 & 5,47 & 5,25 & 4,83 & 4,81 \\
\hline 26 & Sibolga & 5,96 & 5,84 & 5,65 & 5,15 & 5,27 \\
\hline 27 & Tanjung Balai & 5,94 & 5,78 & 5,57 & 5,76 & 5,51 \\
\hline 28 & Pematang Siantar & 5,75 & 6,34 & 5,24 & 4,86 & 4,41 \\
\hline 29 & Tebing Tinggi & 6,01 & 5,45 & 4,90 & 5,11 & 5,14 \\
\hline 30 & Medan & 5,36 & 6,07 & 5,74 & 6,27 & 5,81 \\
\hline 31 & Binjai & 6,07 & 5,83 & 5,40 & 5,54 & 5,39 \\
\hline 32 & Padang Sidempuan & 5,80 & 5,23 & 5,08 & 5,29 & 5,32 \\
\hline 33 & Gunung Sitoli & 6,22 & 6,07 & 5,79 & 6,03 & 6,01 \\
\hline
\end{tabular}

Source: Statistics Indonesia of North Sumatera Province

Based on table 1 above, it can be seen that Mandailing Natal Regency had the highest economic growth compared to other regions in 2017, which was $6.09 \%$; while the second position was occupied by Kota Gunung Sitoli and the third position was Pakphak Barat district at $6.01 \%$ and $5.94 \%$, respectively, while in the fourth position was occupied by Medan City at $5.81 \%$.

Economic development, which is influenced by several macro and micro indicators, has the same goal, namely for the welfare of the community. One of the indicators used is the employment indicator which refers to labor absorption data. The higher the workforce absorbed in an area shows that the area is more capable of providing welfare for its people. In the implementation of national development, the workforce has a very important role and position as actors and objectives of development. By the role and position of the workforce, it is necessary to develop manpower to improve the quality of the workforce and its participation in development and to increase the protection of workers and their families by human dignity.

Manpower development must be regulated in such a way that basic rights and protections are fulfilled for manpower and workers/laborers and at the same time create conditions that are conducive to the development of the business world. Classical wage fun theory predicts that workers would remain at subsistence wage level in long term (Kargi, 2014). One of the important indicators of economic growth and development is the participation rates in the labor force (Dogan, 2017). Manpower development has many dimensions and linkages. This linkage is not only with the interests of the workforce during, before and after the employment period but also with the interests of employers, government and society. For this reason, a comprehensive and comprehensive arrangement is needed, including the development of human resources, increasing the productivity and competitiveness of Indonesian workers, efforts to expand job opportunities, service placement of workers, and fostering industrial relations.

Labour Force Participation Rate (LFPR) of North Sumatera Province seems to increase every year. In 2013, LFPR in North Sumatera was 70.67 percent, in 2014 it fell to 67.07 percent, then in 2015 and 2016 it increased to 67.28 percent and in 2017 it decreased

$$
\text { QE Journal | Vol.09 - No.02 - } 16
$$


again to 68.88 percent. .. Up to 2017, the workforce in North Sumatera was mostly high school education. The percentage of the workforce in this group reaches 36.28 percent, the workforce with education at junior high school and elementary school level is around 21.23 percent and 20.38 percent respectively. Examination of this relationship is important for scholars and policymakers to know the trends in participation in the labor force and to design and implement policies from this point (Chapman, 2015). According to Susetyo (2010) in his study of Fiscal Decentralization, Fiscal Gaps, and Regional Disparities states that fiscal decentralization has not had a significant impact on reducing the fiscal gap in regencies / cities, because of the high level of fiscal dependence on regencies / cities in South Sumatra. . Fiscal decentralization is intended to reduce regional disparities, but fiscal dependence in almost all regencies and cities in South Sumatra is in the category of still lacking.

The North Sumatera Provincial Government in implementing regional autonomy and fiscal decentralization policies has made efforts to implement it based on the needs of each district / city so that a prosperous society is created. The prosperity achieved is not only reflected in high economic growth but is also supported by the fulfillment of realizable consumption needs and the abundant availability of reliable human resources. This study will discuss the effect of two variables contained in fiscal decentralization, the level of public consumption and labor absorption on economic growth in North Sumatera.

\section{REVIEW OF LITERATURE}

\section{Fiscal Decentralization Theory}

Decentralization is an instrument to achieve one of the goals of the state, especially in providing better public services and creating a more democratic public decision-making process. With decentralization, this will be realized in the transfer of authority to lower levels of government to make expenditures, the authority to collect taxing power, the formation of a council elected by the Regional House of Representatives, and assistance in the form of transfers from the Central Government (Sidik, 2002). The implementation of fiscal autonomy and decentralization is marked by the enactment of Law no. 22 of 1999 and Law no. 25 of 1999 on January 1, 2001. During the course of the two laws, these two laws raised several problems which were then corrected by the government through the revision of the law to become Law no. 32 of 2004 and Law no. 33 of 2004 concerning the balance between central and regional finance which was put into effect in December 2004. In-Law no. 32 of 2004, decentralization is defined as the transfer of government authority, by the central government to autonomous regional governments to regulate and manage government affairs in the Republic of Indonesia system.

Rudini (1995) states that fiscal decentralization is the delegation of authority and handover of functions to the regions which is the content of regional autonomy in the context of democratization (politics) and enhancement of national development in the regions by involving the aspirations and participation of the local people about how development is carried out based on perceptions and their will both economically and politically. Given the principle of money follow function in the implementation of

$$
\text { QE Journal | Vol.09 - No.02 - } 17
$$


regional autonomy, fiscal decentralization in Indonesia is a form of the third decentralization (Devolution). Furthermore, Slinko (2002) states that under the concept of "fiscal decentralization" we understand the assignment of fiscal responsibilities to the lower levels of government, that is, the degree of regional (local) autonomy and the authority of local government to decide upon its own expenditure and its ability to generate local revenues.

\section{John Maynard Keynes's Theory of Consumption}

John Maynard Keynes through his book entitled The General Theory of Employment, Interest, and Money which was first published in 1936 put forward a consumption theory called the absolute income theory of consumption or better known as the absolute income hypothesis or absolute income. income hypothesis which is based on the basic psychological laws of consumption (Nanga, 2005). Keynes's theory of consumption basically explains that the consumption of a person and / or society is absolutely determined by the level of income, even if other factors also determine it, according to Keynes, all of them are meaningless and are not very determining.

Mankiw (2002) states that in theory Keynes relies on statistical analysis, and also makes assumptions about consumption based on introspection and causal observations. First and foremost Keynes suspects that the marginal propensity to consume the amount consumed in each additional income is between zero and one. The marginal tendency to consume is a keynote policy recommendation to reduce increasingly widespread unemployment. The power of fiscal policy, to influence the economy as shown by the multiplier of fiscal policy, arises from the feedback between income and consumption. Second, Keynes said that the ratio of consumption to income, which is called average propensity to consume, falls as income rises. He believed that saving was a luxury, so he expected the rich to save a higher proportion of their income than the poor. Third, Keynes argues that income is an important determinant of consumption and that the interest rate does not play an important role. Keynes argues that the effect of the interest rate on consumption is only theoretical. And the conclusion is that the shortrun effect of the interest rate on individual expenditures on income is secondary and relatively insignificant. Based on these three conjectures, Keynes's consumption equation is often written as follows:

$$
\mathrm{C}=\bar{C}+\mathrm{cY}, \bar{C}>0,0<\mathrm{c}<1
$$

Where $\mathrm{C}$ is consumption, $\mathrm{Y}$ is disposable income, is a constant and $\mathrm{c}$ is the marginal propensity to consume (Mankiw, 2002).

Graphically the Keynes consumption function can be described as follows:

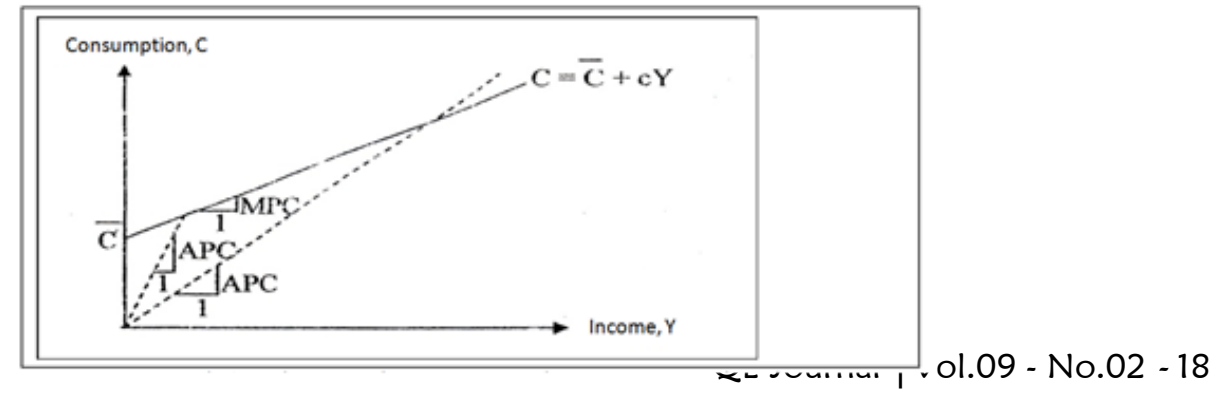


Figure 1. Keynes Consumption Function

\section{Employment Theory}

According to Mulyadi (2003), classical theory considers humans as the main production factor that determines the prosperity of nations. The reason is that nature (land) has no meaning if there are no skilled human resources to cultivate it so that it is beneficial for life. In this case, the classical theory of Adam Smith (1729-1790) also sees that the effective allocation of human resources is the starter of economic growth. After the economy grows, the accumulation of (physical) capital is just beginning to be needed to keep the economy growing. In other words, an effective allocation of human resources is a necessary condition for economic growth.

After Adam Smith, Thomas Robert Malthus (1766-1834) is considered a classical thinker who was instrumental in the development of economic thought. Malthus's most widely known book is Principles of Population. According to Mulyadi (2003), from this book, it will be seen that even though Malthus was one of Adam Smith's followers, not all of his thoughts were in line with Smith's thinking. On the one hand, Smith is optimistic that the welfare of mankind will always increase as a positive impact of the division of labor and specialization. Instead, Malthus was pessimistic about the future of humanity. The fact that land is one of the main production factors remains in number. In many cases, the area of land for agriculture is reduced because some of it is used to build housing, factories and other buildings and build roads. According to Malthus, human development is much faster than the production of agricultural products to meet human needs. Malthus did not believe that technology could develop faster than the population, so it was necessary to limit the population. Malthus called this restriction a moral restriction.

According to Statistics Indonesia, what is meant by the workforce is: "Residents who are already or are currently working, are currently working and are doing other activities such as attending school and taking care of the household. The minimum age limit for workers is 15 years with no maximum age limit. "

From the above understanding, it can be seen that the workforce includes people aged 15 years and over, both those who are already working and those who are still looking for work as well as those who carry out other activities such as schooling, taking care of the household, and other groups who receive income.

\section{Economic Growth Theory}

Prof. Simon Kuznets defines economic growth as "the long-term increase in the ability of a country to provide a wider variety of economic goods to its citizens. This capacity grows according to technological advances, and the institutional and ideological adjustments it requires. "This definition has 3 (three) components: first, the economic growth of a nation is seen from the continuous increase in the supply of goods; second, advanced technology is a factor in economic growth that determines the degree of growth, the ability to supply various kinds of goods to the population; third, the use of QE Journal | Vol.09 - No.02 - 19 
technology broadly and efficiently requires adjustments in the institutional and ideological fields so that the innovations produced by human science can be properly utilized (Jhingan, 2000).

Economic growth is also associated with an increase in "output per capita". In this sense, the theory must include a theory of GDP growth and a theory of population growth. Because only when these two aspects are explained can the development of per capita output be explained. Then the third aspect is economic growth in a long-term perspective, that is if during a long enough period of time the per capita output shows an increasing trend (Boediono, 1999). The economic growth serves as an indication of the success of economic development (Rafiy et al, 2018). To achieve the expected level of economic growth, there are three things that need to be considered, namely: the presence of capital accumulation, population growth, particularly the growth of the workforce and the presence of technological advances (Todaro, 2000).

\section{RESEARCH METHOD}

This research was conducted at the office of the Central Statistics Agency (BPS), North Sumatra Province. The focus of this research is on analyzing the effect of consumption and labor absorption on economic growth in North Sumatra Province. In this study, two explanatory variables that are considered to affect economic growth in North Sumatra Province will be examined, namely:

a) Household Consumption (CONS)

b) Labour Force Participation Rate (LFPR)

The method used by researchers is regression using pooled data or called the panel data regression model. Before knowing panel data regression modeling, it is necessary to study the linear regression model using cross-section data and time series.

The model with cross-section data:

$$
Y_{i}=\alpha+\beta X_{i}+\varepsilon_{i} ; i=1,2, \ldots, N
$$

$\mathrm{N}$ : the amount of cross-section data

Model with time series data

$$
Y_{t}=\alpha+\beta X_{t}+\varepsilon_{t} ; t=1,2, \ldots, T
$$

$\mathrm{N}$ : the amount of time-series data

Considering that panel data is a combination of time series data and cross-section data, in the panel data model, the same unit cross-section is surveyed over time (Gujarati, 2003) and panel data models can be written as:

$$
Y_{i t}=\alpha+\beta X_{i t}+\varepsilon_{i t} ; i=1,2, \ldots, N ; t=1,2, \ldots . ., T
$$

Where :

$i=$ number of observations

$\mathrm{t}=$ amount of time

$i x t=$ amount of panel data 
Several statistical tests can be used to determine the most appropriate approach / method in estimating panel data, namely the Fixed Effect (Chow Test) significance test, the random effect significance test (Lagrange Multiplier / LM test), and the Fixed Effect or random effect significance test. (Hausman test) (Widaryono, 2007). Formal testing to determine which model is better to use is carried out based on statistical decisions. A series of statistical tests that can be carried out consists of several steps. If theoretically it cannot be determined which model to choose, then the basis for selecting the next model can be based on the research sample. If the data is taken from a random sample of individuals over a large population, the random effect is chosen. However, if the sample is the entire population selected, then the Fixed Effect is the right method (Hsiao, 2005).

\section{Chow Test}

The Chow test is a test to compare the Fixed Effect or Common Effect models which is more precise for estimating a panel data (Gujarati, 2003). The hypothesis in the Chow Test is:

$$
\begin{gathered}
\mathrm{H}_{0} \text { : Common Effect Model (CEM) or Pooled Least Square (PLS) } \\
\mathrm{H}_{1} \text { : Fixed Effect Model (FEM) }
\end{gathered}
$$

The basis for rejection of the above hypothesis is to compare the F-statistic calculation with the F-table. If the F-statistic is greater than the F-table, then $\mathrm{HO}$ is rejected, which means that the most appropriate model to use is the Fixed Effect Model. Likewise, if the F-statistic is smaller than the F-table, then $\mathrm{HO}$ is accepted, which means that the most appropriate model to use is the Common Effect Model / FEM or Pooled Least Square / PLS (Widaryono, 2009).

The calculation of F-statistics is obtained by the formula (Baltagi, 2005):

$$
F=\frac{\left(S S E_{1}-S S E_{2}\right) /(n-1)}{\left(S S E_{2}\right) /(n t-n-k)}(3.4)
$$

where $S S E_{1}$ is the sum square error of the Common Effect model, $S S E_{2}$ is the sum square model of the Fixed Effect, $\mathrm{n}$ is the number of cross-section data, $\mathrm{nt}$ is the number of cross-section data times the number of time-series data, and $k$ the number of independent variables (Widaryono, 2007).

While the F-table calculation is obtained from:

$$
\text { F-table }=\{\alpha: d f(n-1, n t-n-k)\}
$$

where $\alpha$ is the level of significance used (alpha), $n$ is the number of cross-section data, $\mathrm{nt}$ is the number of cross-section data times the number of time-series data, and $\mathrm{k}$ is the number of independent variables.

\section{Hausman Test}

The test to compare the Fixed Effect model with the random effect is developed by Hausman (Widaryono, 2007), based on the idea that LSDV in the Fixed Effect method and the GLS method is efficient while the OLS method is inefficient, with the alternative 
of the OLS method being efficient and GLS inefficient. The null hypothesis $\left(\mathrm{H}_{0}\right)$ is that the estimation results of the two are not different.

The Hausman Test method is quite complex. An important element used in the Hausman Test is the covariance matrix of the difference vectors $\left[b^{\wedge}-b^{\wedge} G L S\right]$.

$$
\operatorname{Var}\left[b^{\wedge}-b^{\wedge}{ }_{G L S}\right]=\operatorname{Var}\left[b^{\wedge}\right]+\operatorname{Var}\left[b^{\wedge}{ }_{G L S}\right]-\operatorname{Cov}\left[b^{\wedge}-b^{\wedge} G L S\right]-\operatorname{Cov}\left[b^{\wedge}-b^{\wedge} G L\right]^{\prime} \text { (3.6) }
$$

The result of the Hausman method is that the covariance difference between the efficient and inefficient estimators is zero, so that:

$$
\begin{gathered}
\operatorname{Cov}\left[\left(B^{\wedge}-B^{\wedge}{ }_{G L S),} B^{\wedge}{ }_{G L S}\right]=\operatorname{Cov}\left[B^{\wedge}, B^{\wedge}{ }_{G L S}\right]-\operatorname{Var}\left[B^{\wedge}{ }_{G L S}\right]=0\right. \\
\operatorname{Cov}\left[B^{\wedge}, B^{\wedge}{ }_{G L S}\right]=\operatorname{Var}\left[B^{\wedge}{ }_{G L S}\right]
\end{gathered}
$$

The last equation is put into the first equation (in the Hausman Test) and produces the equation:

$$
\operatorname{Var}\left[b^{\wedge}-b_{G L S}^{\wedge}\right]=\operatorname{Var}\left[b^{\wedge}\right]-\operatorname{Var}\left[b^{\wedge} G L S\right]=\operatorname{Var}(\hat{q})
$$

By following Wald's criteria, the Hausman test follows the chi-square distribution as follows (Widaryono, 2007):

$$
m=\hat{q} \operatorname{Var}(\hat{q})^{-1} q^{\wedge}
$$

After calculating, the results are compared with the distribution table and the number of independent variables. If the calculated Hausman value is greater than the critical value of the Chi-squares table, the Fixed Effect model is better. Conversely, if the Hausman statistical value is smaller than the critical value, then the random effect model is better (Widaryono, 2007).

\section{Assumption Test Analysis}

The classical assumption test is a statistical requirement that must be met in multiple linear regression analysis based on the Ordinary Least Square (OLS). The classic assumption tests that are often used are the multicollinearity test, heteroscedasticity test, and autocorrelation test. The OLS method will produce an estimator that is Best Linear Un] Estimator (BLUE), if the model used, meets the following assumptions:

1. $\left.E \epsilon_{\mathrm{i}}\right)=0$, for each $\mathrm{i}$ The mean value of the bully error is zero for $i=1,2, \ldots, n$

2. $\operatorname{Cov}\left(\epsilon_{\mathrm{i}}, \epsilon_{\mathrm{j}}\right)=0, \mathrm{i} \neq \mathrm{j}$ There is no autocorrelation between bully errors.

3. $\operatorname{Var}\left(\epsilon_{\mathrm{i}}\right)=\sigma^{2}$ Same variance for all confounding errors (assuming homoscedasticity).

4. $\operatorname{Cov}\left(\epsilon_{\mathrm{i}} \mid X_{2 \mathrm{i}}\right)=\operatorname{Cov}\left(\epsilon_{\mathrm{i}} \mid X_{3 \mathrm{i}}\right)=0$

There is no correlation between an independent variable $X$ and confounding error $X_{i}$.

5. There is no multiple collinearities (multicollinearity) between independent variables. 


\section{Autocorrelation Test}

Autocorrelation is defined as the correlation between members of observations in several time series (serial correlation) or between members of observation of various objects or spaces (spatial correlation). Autocorrelation occurs due to economic data slowness factors, specification bias to exclude relevant variables from the model, functional form specification bias, grace period or lag, data manipulation, data transformation, and non-stationarity in the model (Manurung and Rahardja 2005).

The method used to detect autocorrelation is done in four ways, namely the Graph Method, the Run Test, the Durbin-Watson d Test, and the Breusch-Godfrey Test.

The method used in this research is the Durbin-Watson d Test. Autoregression or AR, namely: ${ }^{\varepsilon_{t}}=\rho \varepsilon_{t-1}+v_{t}$ obtained from the rho coefficient value as follows:

$$
\begin{aligned}
& \rho=\frac{\sum_{2}^{T} \varepsilon_{t} \varepsilon_{t-1}}{\sum_{2}^{T} \varepsilon^{2}{ }^{t-1}} \\
& \text { or } \rho=1-0.5 \delta \text { so that } \delta \approx 2(1-\rho) \\
& d=\frac{\sum_{2}^{T}\left(\varepsilon_{t}-\varepsilon_{t-1}\right)^{2}}{\sum_{1}^{T} \varepsilon_{t^{2}}}
\end{aligned}
$$

If $-1 \leq \rho \leq 1$ and $d \approx 2(1-\rho)$ then the statistical value limit $\mathrm{d}$ is $0 \leq d \leq 4$

If $\rho=0$ then $d \approx 2$, meaning there is no serial correlation.

If $\rho=+1$ then $d \approx 0$, meaning that there is a perfect positive serial correlation.

If $\rho=-1$ then $d \approx 4$, meaning that there is a perfect negative serial correlation.

\section{Multicollinearity Test}

Multicollinearity is a perfect linear relationship between the independent variables of a regression model. (Firdaus, 2011). Multicollinearity occurs due to, among other things, the data collection method used to limit the value of the regressor variables, model constraints on the observed population, model specifications, determining the number of independent variables that are more than the number of observations, and timeseries data.

The method used to detect multicollinearity in research is to look at the variance inflating factor (VIF) value, namely:

$$
V I F=\frac{1}{1-r_{12}^{2}}
$$

Where:

$r_{12}{ }^{2}=$ correlation coefficient between $\mathrm{X}_{1}$ and $\mathrm{X}_{2}$ 
VIF indicates that the variance is estimated to increase due to the presence of multicollinearity. The variance of the regression model coefficients is directly proportional to VIF. The inverse or the opposite of VIF is tolerance (TOL), namely:

$$
T O L=\frac{1}{V I F}=1-R_{j}^{2}
$$

Where:

$$
\begin{array}{ll}
R_{j}^{2} & =\text { correlation coefficient } \\
R_{j}^{2} & =1 \text { (perfect multicollinearity), } \mathrm{TOL}=0 \\
R_{j}^{2} & =0 \text { (there is no multicollinearity), TOL }=1
\end{array}
$$

The higher the VIF value, the more serious the multicollinearity problem. The rule used is if VIF is greater than 10 and greater than 0.90 then the variable has high collinearity.

Multicollinearity, according to Frisch, states that a regression model is said to be subject to multicollinearity if there is a perfect or exact linear relationship between some or all of the independent variables of a regression model. As a result, it will be difficult to see the effect of the explanatory variables on the variables described.

\section{Heteroscedasticity Test}

Heteroscedasticity test, testing whether the disturbance variable (disturbance/error terms) that appears in the regression function has the same variance or not. A good model of analysis is if the variance of the disturbance is the same (homoscedastic). The assumption of homoscedasticity from random shocks is the difference or spread or equal scedasticity or equal or homo or equal variance Symbolically homoscedasticity and heteroscedasticity respectively are written as follows:

$$
\begin{array}{ll}
E\left[\varepsilon_{i}^{2}\right]=\sigma^{2} & \mathrm{t}=1,2, \ldots, \mathrm{T} \\
E\left[\varepsilon_{i}^{2}\right]=\sigma_{i}^{2} & \mathrm{t}=1,2, \ldots, \mathrm{T}
\end{array}
$$

The difference between homoscedasticity and heteroscedasticity can be seen from the causes of heteroscedasticity. Heteroscedasticity can be detected using the Image method (Gujarati, 2003), namely:

1. If there is a certain pattern in the distribution of the points of the disturbance variable, then there has been heteroscedasticity.

2. Conversely, if there is no clear pattern, the points of the disturbance variable spread above and below 0 (zero), then there is no heterocedacity.

\section{RESULT AND DISCUSSION}

\section{Consumption}

Public consumption in this study was the amount of consumption spent by households from 2013 to 2017. Household consumption in North Sumatera during the study year was described in Figure 2 below.

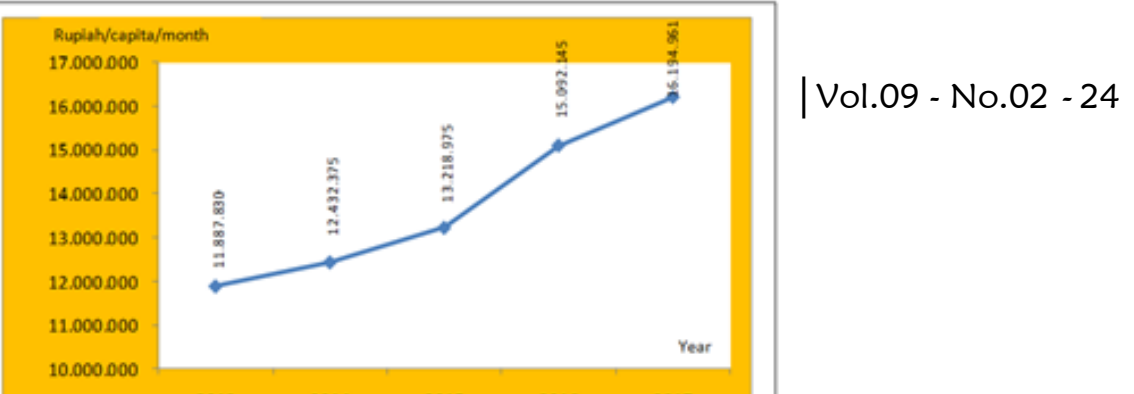


Source: Statistics Indonesia of North Sumatera Province

Figure 2. The Developments in the Level of Consumption in North Sumatera 2013-2017

Figure 2 explained that during the period 2013 to 2017, it showed the development of an increasing level of public consumption. At the beginning of the research year, namely 2013, the total consumption of the people of North Sumaetra province was Rp. $11,887,830$ per month.

\section{Labour Force Participation Rate (LFPR)}

Workers are residents aged 15 years and over who carry out economic activities continuously for at least 2 hours to get remuneration in the form of goods or services. Included here is the activity of helping other family members without receiving payment. Like a child helping his parents in the fields, looking after the shop, and so on. (Statistics Indonesia, 2018).

In 2013 the Labor Force Participation Rate in North Sumatera Province was 70.67 percent, decreasing in 2014 to 67.07 percent. In 2015 there was an increase in LFPR to 67.67 percent, in 2016 it was 67.28 percent and in 2017 it was 68.88 percent.

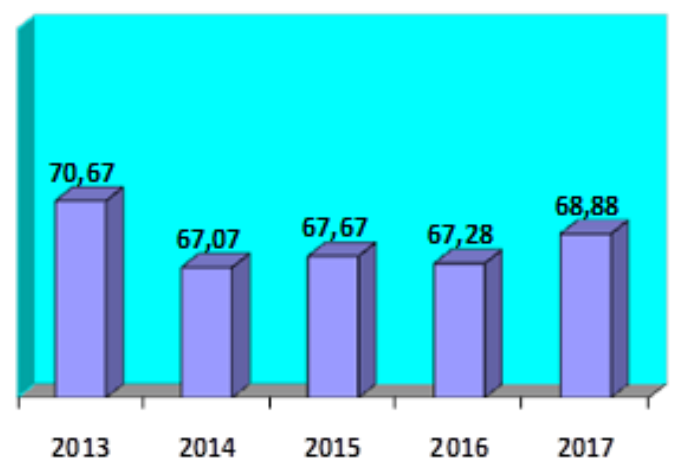

Source: Statistics Indonesia of North Sumatera Province

Figure 3. LFPR of North Sumatera Province 2013-2017

Although the population aged 15 years and over who work in North Sumatera had fluctuated, in general, the number had increased from the study period, namely from 2013 to 2017.

As for the regencies/municipalities of North Sumatera province in 2017, the largest TPAK was in West Pakpak Regency at 90.53 percent, followed by Samosir and Humbang Hasundutan Regency, respectively 88.87 percent and 87.74 percent. While the least 
amount was in Labuhan Batubara Regency at 56.15 percent, Binjai city at 62.03 percent and Labuhan Batu Utara Regency at 62.91 percent.

\section{Panel Data Regression Model Suitability Test}

Three types of panel data regression models are generally used, namely the Command Effects Model (Pooled Least Square - PLS), the Fixed Effects Model (Fixed Effects Model - MET), and the Random Effects Model (Random Effects Model - MER). The test that must be done to determine the best panel data regression model is the Chow test, Hausman test and Lagrange Multiplier (LM) test.

\section{Chow Test}

This test is conducted to determine whether the Common Effect (CE) or Fixed Effect (FE) model is the most appropriate to be used in estimating panel data. The hypothesis used is:

$$
\begin{gathered}
\mathrm{H}_{0} \text { : Select Common Effect (CE) } \\
\mathrm{H}_{1} \text { : Select Fixed Effect (FE) }
\end{gathered}
$$

The decision making for the Chow test is to look at the probability value (Prob.) For Cross-section F. If the value is $>0.05$, the model chosen is Common Effect (CE), but if the Prob value obtained is $<0.05$, the model Fixed Effect (FE) is selected.

Table 2. Chow Test Results

Redundant Fixed Effects Tests

Pool: Untitled

Test cross-section fixed effects

\begin{tabular}{llll}
\hline \hline Effects Test & Statistic & d.f. & Prob. \\
\hline \hline Cross-section F & 18.735831 & $(32,128)$ & 0.0000 \\
\hline \hline
\end{tabular}

Cross-section fixed effects test equation:

Dependent Variable: LOG(PE?)

Method: Panel EGLS (Cross-section weights)

Date: 12/12/19 Time: 03:20

Sample: 20132017

Included observations: 5

Cross-sections included: 33

Total pool (balanced) observations: 165

Use pre-specified GLS weights

White cross-section standard errors \& covariance (d.f. corrected)

\begin{tabular}{lllll}
\hline \hline & Coefficient & Std. Error & t-Statistic & Prob. \\
\hline \hline C & 3.324841 & 0.417668 & 7.960487 & 0.0000 \\
LOG(CONS?) & -0.023186 & 0.016036 & -1.445902 & 0.1502
\end{tabular}

QE Journal | Vol.09 - No.02 - 26 


\begin{tabular}{|c|c|c|c|}
\hline LOG(LFPR?) & -0.055007 & -1.266451 & 0.2072 \\
\hline & \multicolumn{3}{|c|}{ Weighted Statistics } \\
\hline R-squared & 0.091193 & Mean dependent var & 3.846359 \\
\hline Adjusted R-squared & 0.068473 & S.D. dependent var & 2.269982 \\
\hline S.E. of regression & 0.218876 & Akaike info criterion & 2.908522 \\
\hline Sum squared resid & 7.665106 & Schwarz criterion & 3.002642 \\
\hline Log-likelihood & -234.9531 & Hannan-Quinn criter. & 2.946729 \\
\hline F-statistic & 4.013749 & Durbin-Watson stat & 0.421991 \\
\hline \multirow[t]{2}{*}{ Prob(F-statistic) } & 0.003950 & & \\
\hline & \multicolumn{3}{|c|}{ Unweighted Statistics } \\
\hline R-squared & -0.025716 & Mean dependent var & 1.684839 \\
\hline Sum squared resid & 3.662827 & Durbin-Watson stat & 0.861297 \\
\hline
\end{tabular}

Source: Panel data output results processed with Eviews 7.0

From the results of processing the chow test data presented in table 2 above, the Prob value is obtained. The cross-section $\mathrm{F}$ is 0.0000 , which means that the value obtained is $<0.05$, so it can be concluded that the Fixed Effect model is more precise than the Common Effect model.

\section{Hausman Test}

This test is conducted to determine whether the Fixed Effect or Random Effect model is most appropriate. The hypothesis used is:

$$
\begin{gathered}
\mathrm{H}_{0} \text { : Select the Random Effect (RE) } \\
\mathrm{H}_{1} \text { : Select Fixed Effect (FE) }
\end{gathered}
$$

The decision making for the Hausman test is to look at the probability value (Prob.) For the random cross-section. If the Prob Cross Section Random value is $>0.05$, the chosen model is Random Effect, but if the Prob Cross Section Random value is $<0.05$, the chosen model is Fixed Effect.

Table 3. Hausman Test Results

Correlated Random Effects - Hausman Test

Pool: Untitled

Test cross-section random effects

\begin{tabular}{llcc}
\hline \hline Test Summary & \multicolumn{2}{c}{ Chi-Sq. Statistic Chi-Sq. d.f. } & Prob. \\
\hline \hline Cross-section random & 25.327398 & 4 & 0.0000 \\
\hline \hline
\end{tabular}

Cross-section random effects test comparisons: 


\begin{tabular}{|c|c|c|c|c|}
\hline Variable & Fixed & Random & $\operatorname{Var}($ Diff.) & Prob. \\
\hline $\begin{array}{l}\text { LOG(CONS?) } \\
\text { LG(IFPR?) }\end{array}$ & -0.206675 & $\begin{array}{l}-0.165268 \\
0106798\end{array}$ & 0.007798 & 0.6391 \\
\hline LUG(LFPR?) & & & & \\
\hline \multicolumn{5}{|c|}{$\begin{array}{l}\text { Cross-section random effects test equation } \\
\text { Dependent Variable: LOG(PE?) } \\
\text { Method: Panel Least Squares } \\
\text { Date: } 12 / 26 / 19 \text { Time: } 07: 45 \\
\text { Sample: } 20132017 \\
\text { Included observations: } 5 \\
\text { Cross-sections included: } 33 \\
\text { Total pool (balanced) observations: } 165\end{array}$} \\
\hline & Coefficient & Std. Error & t-Statistic & Prob. \\
\hline $\mathrm{C}$ & 4.030675 & 1.714193 & 2.351354 & 0.0202 \\
\hline LOG(CONS?) & -0.206675 & 0.109181 & -1.892956 & 0.0606 \\
\hline LOG( LFPR?) & 0.762687 & 0.222690 & 3.424877 & 0.0008 \\
\hline \multicolumn{5}{|c|}{ Effects Specification } \\
\hline \multicolumn{5}{|c|}{ Cross-section fixed (dummy variables) } \\
\hline R-squared & 0.536128 & \multicolumn{2}{|c|}{ Mean dependent var } & 1.684839 \\
\hline Adjusted R-squared & 0.405664 & \multicolumn{2}{|c|}{ S.D. dependent var } & 0.147561 \\
\hline S.E. of regression & 0.113760 & \multicolumn{2}{|c|}{ Akaike info criterion } & -1.314886 \\
\hline Sum squared resid & 1.656485 & \multicolumn{2}{|c|}{ Schwarz criterion } & -0.618401 \\
\hline Log-likelihood & 145.4781 & \multirow{2}{*}{\multicolumn{2}{|c|}{ Hannan-Quinn criter. }} & -1.032158 \\
\hline F-statistic & 4.109397 & & & 1.751298 \\
\hline Prob(F-statistic) & 0.000000 & \multicolumn{2}{|c|}{ Durbin-Watson stat } & \\
\hline
\end{tabular}

Source: Panel data output results processed with Eviews 7.0

From the results of data processing, it can be seen that the Prob. The random crosssection is 0.0000 , which means that the value obtained is $<0.05$, so it can be concluded that the Fixed Effect model is more appropriate than the Random Effect model.

\section{Classical Assumption Test Results}

The model used in this study is multiple linear regression, so a classic assumption test is needed to determine whether or not there is a violation of the assumption. The assumption is the absence of heteroscedasticity (heteroscedasticity), multicollinearity (multicollinearity) and autocorrelation (autocorrelation). The fulfillment of classical assumptions is needed so that the model can be used as a good prediction tool by meeting the standard conditions of Best Linear Unavailable Estimation (BLUE). A 
normality test is also carried out on research data to see whether the research data has followed the normal distribution.

\section{Multicollinearity}

One of the assumptions used in the OLS method is that there is no linear relationship between the independent variables. The existence of a relationship between the independent variables in regression is called multicollinearity. If there are symptoms of multicollinearity, the estimator coefficient is still BLUE (Best Linear Unepang Estimator), but the OLS estimator has large variants and covariances, making the estimate less accurate and sensitive to slight changes in data. One way to detect multicollinearity symptoms, seen from a high R2 value and more independent variables that are not significant than the significant independent variables or even none of the independent variables are significant.

Table 4. The Value of the Correlation Matrix of the Independent Variables of Economic Growth

\begin{tabular}{|l|l|l|}
\hline VAR & CONS & LFPR \\
\hline CONS & 1.000000 & 0.014640 \\
\hline LFPR & 0.014640 & 1.000000 \\
\hline
\end{tabular}

Source: Data Processing Results

From Table 4, it can be seen that the correlation matrix value shows that there is no multicollinearity of data. A variable is said to have multicollinearity if the correlation between the two variables is more than the value of $R$ squared. Based on the results of regression calculations, no variable has a value higher than 0.840110 for the economic growth function. To further emphasize that the independent variables used do not contain multicollinearity problems, the test is continued by looking at the variance inflating factor (VIF) value, namely:

$$
V I F=\frac{1}{1-r_{12}^{2}}
$$

Where:

$r_{12}{ }^{2}=$ correlation coefficient between $\mathrm{X}_{1}$ and $\mathrm{X}_{2}$

The higher the VIF value, the more serious the multicollinearity problem. The rule used is if VIF is greater than 10 and greater than 0.90 then the variable has high collinearity. The following is presented in Table 5 of the estimation results of the VIF value for each of the independent variables of economic growth.

Table 5. VIF Value of Economic Growth Free Variables

\begin{tabular}{|l|l|l|}
\hline VAR & CONS & LFPR \\
\hline CONS & 0 & 1,000214 \\
\hline LFPR & 1,000214 & 0 \\
\hline
\end{tabular}

Source: Data Processing Results

QE Journal | Vol.09 - No.02 - 29 
The estimation results show that all independent variables of the economic growth model have a VIF value $<10$, this indicates that the independent variables used do not have high collinearity or are free from multicollinearity problems.

\section{Heteroskedasticity}

The consequence of heteroscedasticity is that the estimation results no longer have a minimum variant, and the estimators no longer produce BLUE estimators, because the standard error calculations are no longer reliable and hypothesis testing is based on the $t$ and $F$ distributions can no longer be trusted for evaluating the regression results.

One of the tests that can be done to determine whether there is heteroscedasticity or not is by using the White method. The null hypothesis in this test is that there is no heteroskedasticity.

The method used is the Fixed Effect Models method, so a simple test is carried out with the following steps:

1. Perform regression with the OLS method

2. Perform regression using the OLS method with white heteroskedasticity.

3. Comparing $R 2$ of the two regression results. If $R^{2}$ is relatively the same, then there is no heteroscedasticity. Conversely, if $R^{2}$ is significantly different, then there is heteroscedasticity.

Table 6. Heteroscedasticity Test Results

Dependent Variable: LOG(PE?)

Method: Pooled EGLS (Cross-section weights)

Date: 12/12/19 Time: 20:25

Sample: 20132017

Included observations: 5

Cross-sections included: 33

Total pool (balanced) observations: 165

Linear estimation after one-step weighting matrix

White cross-section standard errors \& covariance (d.f. corrected)

\begin{tabular}{lllll}
\hline \hline Variable & Coefficient & Std. Error & t-Statistic & Prob. \\
\hline \hline C & 3.889996 & 0.365137 & 10.65353 & 0.0000 \\
LOG(CONS?) & -0.185883 & 0.021147 & -8.790169 & 0.0000 \\
LOG(LFPR?) & 0.442641 & 0.043204 & 10.24526 & 0.0000 \\
\hline \hline
\end{tabular}

Effects Specification

Cross-section fixed (dummy variables)

Weighted Statistics

\begin{tabular}{|c|c|c|c|}
\hline R-squared & 0.840110 & Mean dependent var & 3.846359 \\
\hline
\end{tabular}




\begin{tabular}{llll} 
Adjusted R-squared & 0.795141 & S.D. dependent var & 2.269982 \\
S.E. of regression & 0.102643 & Sum squared resid & 1.348551 \\
F-statistic & 18.68198 & Durbin-Watson stat & 1.865543 \\
Prob(F-statistic) & 0.000000 & & \\
\hline
\end{tabular}

After testing, the $R 2$ results are usually relatively equal to 0.840110 and $R^{2}$ white is equal to 0.840110 . So there is no heteroscedasticity problem. The estimation results of this research model are good and can be analyzed.

\section{Autocorrelation}

Autocorrelation problems are caused by the correlation between the residuals of one observation and the residuals of other observations. Autocorrelation problem detection is done by using the Durbin-Watson (DW) method.

Based on the results of the model estimation, it is known that the calculated DurbinWatson (DW) value is 1.865543 . The calculated Durbin-Watson value is compared with the Durbin-Watson table value ( $\alpha=5 \%$, the number of observations $(n)$ is 165 and the number of independent variables ( $k$ ) is 4$)$, then the value is obtained according to the following figure:

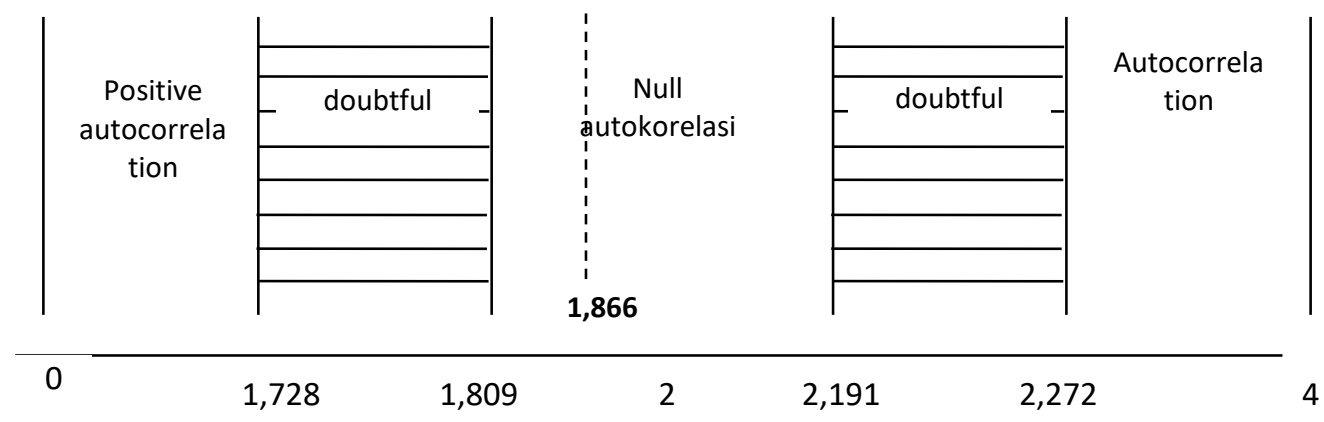

Figure 2. Autocorrelation Test with the Durbin-Watson Method

According to Durbin-Watson's criteria, the calculated DW value is in the "no autocorrelation" area. Thus, at the level $\alpha=5 \%$, the estimated model does not experience autocorrelation problems.

\section{Discussion}

Estimation experiments are carried out on variables that are considered to affect economic growth, such as consumption and labor force participation rates. The significant estimation results are given the variables of local revenue, balance funds and the level of labor force participation.

Estimation results for all regencies/cities in North Sumaetra province based on the highest regression coefficient are Deli Serdang Regency with a regression coefficient of 0.295459 , followed by Medan City at 0.258016 and Mandailing Natal Regency at 0.164286 . The lowest regression coefficient was in South Nias Regency at -0.321165 , followed by Central Tapanuli Regency at -0.286510 and West Nias Regency at -0.241659 . 
The estimation results show the regression coefficient of the KONS variable is -0.185883 . This means that with each increase in CONS by 1 percent, economic growth will decrease by 0.18 percent and vice versa. The effect of the CONS variable on EG was negative and significant at the 95 percent confidence level.

The results of this study can be explained that the influence of the level of consumption variable on economic growth is indirect, that is, when consumption will increase because people's income also increases. An increase in people's income will be in line with economic growth, where an economy that is experiencing an increase will automatically increase people's income and the level of consumption will also increase.

Keynes's theory states that the ratio of consumption to income, called average propensity to consume, falls as income rises. This means that when income increases the tendency to consume both food and non-food in the long run will decrease, as the difference from income will be saved as an investment so that people who have a greater income at a certain point will not spend their income on consumption but instead make it an investment.

This condition can also be explained that when people's consumption increases, it does not mean that it is due to increased income, this is also influenced by an increased level of need such as high education costs, expensive medical costs, lifestyle and others, and not to cover it from income as well. increase but rather from loans or debt and credit.

Thus the results of this study are also in line with previous research conducted by Aminah entitled the effect of investment, labor and consumption on economic growth in Padang City which states that consumption variables have a negative and significant effect on economic growth in Padang City. The estimation results show the regression coefficient of LFPRvariable is 0.442641 . This means that for each increase in LFPR by 1 percent, economic growth will increase by 0.44 percent and vice versa. The effect of the LFPR variable on EG is significant at the 95 percent confidence level.

The results of previous research and the classical theory of Adam Smith that the effective allocation of human resources is economic growth. In other words, an effective allocation of human resources is a necessary condition for economic growth. Meanwhile, from previous research by Pujiati (2002), the result is that labor as an important factor in accelerating economic growth has a positive and significant effect on economic growth.

\section{CONCLUSIONS AND RECOMMENDATIONS}

\section{Conclusion}

The results of this study can be explained that the influence of the level of consumption variable on economic growth is indirect, that is, when consumption will increase because people's income also increases. An increase in people's income will be in line with economic growth, where an economy that is experiencing an increase will automatically increase people's income and the level of consumption will also increase. The influence of Labour Force Participation Rate (LFPR) variable on Economic Growth is significant at the 95 percent confidence level. In other words, the level of labor force 
participation has a positive and significant effect on the economic growth of the regencies / cities of North Sumatera Province. The estimation results show that Labour Force Participation Rate (LFPR) variable has the greatest influence on the Economic Growth model compared to the Consumption variable in the regencies/cities of North Sumatera Province.

\section{REFERENCES}

Arsyad, Lincolin. 1997. Ekonomi Pembangunan, STIE YKPN, Yogyakarta.

Baltagi, H. Bagi. (2005). Econometric Analysis of Panel Data.John Wiley \& Sons Canada. Boediono. 1999. Teori Pertumbuhan Ekonomi. Yogyakarta: BPF

Chapman, K. A. (2015), Economic Development and Female Labor Force Participation in the Middle East and North Africa: A Test of the U-Shape Hypothesis, Gettysburg Economic Review, Vol.8, no.3, pp.5-22

Doğan, Buhari. 2017. Female Labor Force Participation Rate and Economic Growth in the Framework of Kuznets Curve: Evidence From Turkey. Review of Economic and Business Studies. 10. 33-54. 10.1515/rebs-2017-0047.

Firdaus, Muhammad, 2011. Ekonometrika: Suatu Pendekatan Aplikatif, Edisi Kedua, Cetakan Pertama, Jakarta : Bumi Aksara.

Gujarati. Damodar. 2003. Ekonometri Dasar. Terjemahan: Sumarno Zain. Jakarta:Erlangga.

Hsiao, Cheng. (2005). The Analysis of Panel Data. 10.1017/CBO9780511754203.

Jhingan. 2000. Ekonomi Pembangunan dan Perencanaan. Jakarta : Rajawali Press.

Kargi, Bilal. (2014). Labor Force Participation Rate and Economic Growth: Observations for Turkey. Universal Journal of Management and Social Sciences. 4. 46-54.

Mankiw, Gregory. (2002). Macroeconomics, 5th ed. Worth Publishers.

Manurung, Mandala., and Rahardja, Pratama. 2004. Pengantar Ilmu Ekonomi Mikroekonomi dan Makroekonomi, Edisi Revisi. Jakarta: LPFE UI.

Mulyadi, S. 2003. Ekonomi Sumber Daya Manusia dalam Perspektif Pembangunan. Jakarta: PT. Raja Grafindo Persada.

Nanga, Muana. 2005. Makro Ekonomi: Teori, Masalah, dan Kebijakan, Jakarta: PT Grafindo Persada.

Pujiati, Amin. 2008. Analisis Pertumbuhan Ekonomi di Karesidenan Semarang Era Desentralisasi Fiskal. 13.

Rafiy et al. 2018. An Analysis of the Effect of Consumption Spending and Investment on Indonesia's Economic Growth. Iran Economic Review, 22(3).

Richna, Handriyani., M.M. Sahyar., and M. Arwansyah. 2018. Analysis of the Effect of Household Consumption Expenditure, Investment and Labor to Economic Growth: 
A Case in Province of North Sumatra. Studia Universitatis „Vasile Goldis" Arad Economics Series, 28(4).

Rudini. 1995. Otonomi Daerah dan Tantangan, PT Sinar Agape Press, Jakarta.

Sidik, Machfud and Kadjatmiko (2002). Indonesian's fiscal decentralization: combining expenditure assignment and revenue assignment. Paper of Georgia State University, Atlanta.

Slinko, Irina. 2002. Fiscal Decentralization on The Budget Revenue Inequity among Munipacalities and Growth Russian Regions.

Statistics Indonesia of North Sumatera Province (2009), Daerah Dalam Angka, PDRB dan Penduduk, tahun 2005-2009.

Susetyo, Didik. 2010. Desentralisasi Fiskal, Kesenjangan Fiskal, dan Disparitas Regional. Makalah Pidato Pengukuhan Guru Besar Fakultas Ekonomi Universitas Sriwijaya. Penerbit Universitas Sriwijaya, Palembang.

Todaro. Michael P. 2000. Pembangunan Ekonomi. Jakarta: Bumi Aksara.

Widarjono, Agus. 2007. Ekonometrika: Teori dan aplikasi untuk ekonomi dan bisnis. Yogyakarta: Ekonisia 